\title{
NILAI MORAL DAN SOSIAL TRADISI PAMALI DI KAMPUNG ADAT KUTA SEBAGAI PENDIDIKAN KARAKTER
}

\author{
Hendry Sugara ${ }^{1}$, Teguh Iman Perdana ${ }^{2}$ \\ ${ }^{1,2}$ Pendidikan Bahasa dan Sastra Indonesia, STKIP Yasika Majalengka \\ Jalan Kasokandel Timur 64, Kabupaten Majalengka, Jawa Barat \\ 1e-mail: brohendrysugara@gmail.com
}

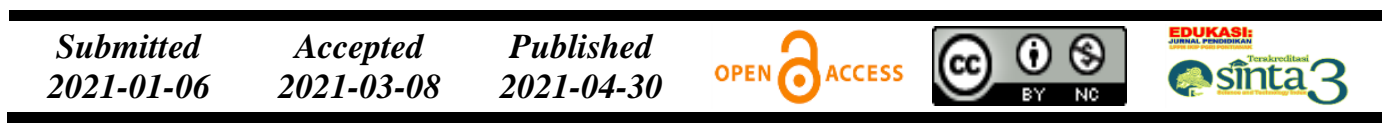

\begin{abstract}
Abstrak
Penelitian bertujuan untuk mendesripsikan pendidikan karakter melalui tradisi pamali di Kampung Adat Kuta. Jenis penelitian adalah kualitatif deskriptif dengan menggunakan pendekatan etnografi. Instrumen dalam penelitian adalah peneliti sendiri. Pengumpulan data dilakukan dengan observasi, wawancara, dan dokumentasi. Teknik analisis data menggunakan tiga cara, yaitu reduksi, penyajian, dan verifikasi data. Hasil penelitian menunjukkan bahwa terdapat dua nilai dalam tradisi pamali di Kampung Adat Kuta, yaitu: nilai moral yang mengajarkan tentang sikap disiplin dan peduli lingkungan; serta nilai sosial yang berupa sikap rendah hati dan kesopanan. Nilai-nilai tersebut dapat diaplikasikan dalam kehidupan sehari-hari di masyarakat.
\end{abstract}

Kata Kunci: nilai moral; nilai sosial; tradisi pamali; pendidikan karakter.

\begin{abstract}
The research aimed to describe the character of education through the pamali tradition in the Kuta Traditional Village. The type of research was descriptive qualitative using an ethnographic approach. The instrument in the research was the researcher itself. Data collection was carried out by observation, interviews, and documentation. The data analysis technique used three methods, namely data reduction, presentation, and verification. The results showed that there are two values in the pamali tradition in Kuta Traditional Village, namely: moral values that teach discipline and care for the environment; and social values in the form of humility and politeness. These values can be applied in everyday life in society.
\end{abstract}

Keywords: moral values; social values; pamali tradition; character education.

\section{PENDAHULUAN}

Indonesia merupakan bangsa yang memiliki aneka ragam budaya peninggalan nenek moyang yang sampai sekarang masih dilaksanakan dalam kelompok masyarakat adat dan menjadi kekayaan nasional. Kelompok masyarakat adat sangat memercayai kebenaran nilai-nilai lokal untuk dijadikan pegangan hidup dalam menjalani kehidupan di masyarakat secara turun-temurun. Jika 
ditelaah secara mendalam tentang budaya yang ada di masyarakat, maka akan ditemukan nilai pendidikan karakter (Yuliananingsih, 2015; Herlina, 2014).

Nilai-nilai budaya lokal sekarang mulai terabaikan. Hal tersebut karena dampak negatif dari globalisasi yang semakin berkembang, sehingga perlahanlahan mulai menggeser eksistensi budaya lokal. Untuk menghadapi dampak negatif dari globalisasi tersebut, diperlukan berbagai pendekatan sebagai usaha mencari solusi. Salah satunya dengan mengerahkan segala potensi yang dimiliki bangsa, termasuk nilai-nilai yang terkandung dalam budaya lokal suatu masyarakat adat. Budaya lokal adalah modal besar bagi masyarakat yang dapat tumbuh dan berkembang secara turun-temurun (Hemafitria, 2019; Hikmat, 2010). Budaya lokal harus tetap dipertahankan untuk menjaga masyarakat dari dampak negatif globalisasi, terutama generasi muda. Adanya perubahan kebudayaan di masyarakat karena adanya perkembangan teknologi, walaupun masih ada juga masyarakat yang mempertahankan budaya agar dapat terus bertahan dari terjangan globalisasi (Mauludea et al., 2016).

Globalisasi banyak memberikan pengaruh negatif terhadap kebudayaan lokal, seperti nilai-nilai budaya bangsa yang semakin luntur dan tergeserkan oleh budaya asing yang kurang baik jika diberikan kepada generasi muda karena bertentangan dengan budaya bangsa. Hal tersebut menunjukkan bahwa masyarakat belum mampu menghadapi gempuran budaya asing di era globalisasi. Budaya asing merupakan ancaman bagi budaya lokal yang merupakan ciri khas suatu negeri (Alma, 2010). Kearifan lokal menjadi hal yang wajib untuk diwariskan kepada generasi muda sebagai penerus bangsa. Generasi penerus yang lahir di zaman modern, tentu tidak akan begitu saja menerima warisan budaya lokal. Generasi penerus akan menyeleksi budaya yang diwariskan dan mengambil yang sesuai dengan kepentingan dirinya. Budaya yang sesuai dengan kondisi sekarang akan dipertahankan untuk diwariskan kepada generasi selanjutnya (Saini, 2004). Proses penyeleksian akan optimal jika generasi muda dikenalkan pada budaya lokal, salah satunya yang ada di Kampung Adat Kuta.

Nilai budaya Kampung Adat Kuta sangat dipengaruhi oleh keadaan alam. Lingkungan dan budaya merupakan produk campuran yang tercipta melalui 
Edukasi: Jurnal Pendidikan, Volume 19 Nomor 1 Tahun 2021

Nilai Moral dan Sosial Tradisi Pamali.......

Hendry Sugara, Teguh Iman Perdana

Halaman 1-15

dialektika (Steward dalam Susilo \& Rahmat, 2009). Nilai-nilai lokal yang berkembang dalam masyarakat Kampung Adat Kuta juga dipengaruhi keadaan alamnya. Leuweung ruksak, cai beak, manusia balangsak (hutan rusak, air habis, manusia sengsara) merupakan jargon yang terdapat di Kampung Adat Kuta. Berpegang dari jargon tersebut, masyarakat Kampung Adat Kuta sangat menjaga hutan, sehingga terdapat beberapa larangan/aturan yang memiliki makna untuk pelestarian lingkungan, seperti dilarang mengganggu satwa, membuang hajat di hutan, menggunakan alat dari besi ketika membersihkan hutan, dan sebagainya.

Salah satu nilai budaya masyarakat Kampung Adat Kuta adalah tradisi pamali. Tradisi pamali dapat direlevansikan menjadi nilai pendidikan karakter. Pendidikan karakter tersebut berupa nilai moral dan sosial. Nilai-nilai tersebut akan memberikan dampak positif bagi generasi muda yang mulai meninggalkan budaya lokal. Menanamkan pendidikan karakter melalui budaya lokal juga merupakan upaya menjaga eksistensi budaya agar tidak punah. Pendidikan karakter merupakan suatu hal yang penting dalam membangun sumber daya manusia yang memiliki karakter positif. Pembentukan karakter harus dilakukan sejak dini. Pembentukan karakter pada anak merupakan pondasi dasar untuk membangun bangsa agar menjadi lebih maju (Adri et al., 2020). Masyarakat harus mengenal karakter bangsa dan kemudian harus diterapkan dalam kehidupan sehari-hari. Cara menyampaikan ke masyarakat yaitu melalui proses pendidikan. Proses tersebut tidak hanya menyampaikan ilmu saja, melainkan harus sampai kepada nilainya (Anggraeni, 2018). Pendidikan karakter perlu diterapkan ke generasi muda melalui pendidikan formal atau nonformal (Rachmadyanti, 2017).

Moral generasi muda sekarang berada dalam kondisi kritis. Jika dilihat, keadaan masyarakat terutama pada generasi muda sudah tidak lagi memperhatikan persoalan moral (Budiarto, 2020). Begitu juga dengan permasalahan sosial yang terus berkembang di masyarakat, akibat dari pengaruh budaya asing. Oleh karenanya, berdasarkan permasalahan yang telah diuraikan, maka tujuan penelitian adalah untuk mendeskripsikan pendidikan karakter melalui tradisi pamali di Kampung Adat Kuta. 


\section{METODE}

Jenis penelitian menggunakan kualitatif deskriptif dengan pendekatan etnografi. Pendekatan etnografi sangat mengutamakan adanya sense of reality peneliti, yang merupakan proses berpikir mendalam dan menginterpretasikan fakta berdasarkan konsep atau teori yang digunakan. Perlu pemahaman yang mendalam untuk mengembangkannya dan mengutamakan nilai-nilai yang diteliti. Objek penelitian adalah nilai-nilai pendidikan karakter yang terdapat dalam tradisi pamali yang ada di Leuweung Kramat, Kampung Adat Kuta, Kabupaten Ciamis, Jawa Barat. Instrumen penelitian adalah peneliti sendiri. Alasannya yaitu segala sesuatu yang ada di lapangan bersifat belum pasti. Dalam keadaan yang serba tidak pasti dan tidak jelas, tidak ada pilihan lain dan hanya peneliti sebagai alat satu-satunya yang dapat mencapainya. Teknik pengumpul data menggunakan observasi, wawancara, dan dokumentasi.

Peneliti melakukan observasi awal untuk melihat kondisi lapangan dan mendapatkan data awal. Selanjutnya, peneliti melakukan wawancara terhadap juru kunci/kuncen Leuweung Kramat, Aki Maryono. Dokumentasi tentang Kampung Adat Kuta, peneliti dapatkan dari Ketua Adat, berupa laporan penelitian-penelitian sebelumnya. Teknik analisis data menggunakan reduksi, penyajian, dan verifikasi data. Tabel 1 memperlihatkan aspek-aspek yang digunakan sebagai pedoman observasi, dan wawancara.

Tabel 1 Aspek-Aspek Pedoman Observasi dan Wawancara

\begin{tabular}{cl}
\hline Instrumen & \multicolumn{1}{c}{ Aspek } \\
\hline Observasi & Wilayah, budaya, lingkungan, juru kunci/kuncen, dan fasilitas \\
& umum. \\
Wawancara & Nilai moral: disiplin dan peduli lingkungan. \\
& Nilai sosial: rendah hati dan kesopanan. \\
\hline
\end{tabular}

\section{HASIL DAN PEMBAHASAN}

Nilai pendidikan karakter tradisi Kampung Adat Kuta tercermin dari sikap masyarakatnya yang memiliki kepercayaan dan dapat dijadikan teladan. Kepercayaan tersebut diwariskan secara turun-temurun. Kepercayaan tersebut berupa tradisi pamali yang mengatur masyarakat setempat maupun orang luar saat 
Edukasi: Jurnal Pendidikan, Volume 19 Nomor 1 Tahun 2021

Nilai Moral dan Sosial Tradisi Pamali.......

Hendry Sugara, Teguh Iman Perdana

Halaman 1-15

memasuki Leuweung Kramat. Semua aturan yang berlaku di Kampung Adat Kuta harus ditaati oleh semua orang. Jika ada yang melanggar, maka akan akan terjadi hal-hal yang tidak diinginkan. Tradisi pamali tersebut bukan sebuah aturan yang diciptakan oleh para leluhur sekadar larangan-larangan yang tanpa makna. Peneliti menemukan dua nilai yang terdapat dari tradisi pamali Kampung Adat Kuta, yaitu nilai moral dan nilai sosial. Nilai moral terdiri dari disiplin dan peduli lingkungan, sedangkan nilai sosial terdiri dari rendah hati dan kesopanan.

\section{Nilai Moral dalam Tradisi Pamali di Kampung Adat Kuta}

Berdasarkan hasil analisis, nilai pertama yang ditemukan adalah nilai moral. Moral berkaitan dengan sikap baik dan buruknya manusia sebagai makhluk yang memiliki akal (Chastanti \& Munthe, 2019; Salfia, 2015). Terdapat dua nilai moral yang berhubungan dengan sikap/perbuatan, akhlak, dan budi pekerti yang dapat dijadikan pedoman dalam berperilaku dalam kehidupan bermasyarakat, yaitu disiplin dan peduli lingkungan.

\section{Disiplin}

Nilai disiplin dapat dilihat dari sikap yang menunjukkan perilaku taat terhadap tata tertib atau peraturan yang berlaku. Jika seseorang memiliki sikap disiplin, maka akan muncul karakter lain berupa sikap-sikap yang baik (Octavia \& Sumanto, 2018; Lestari \& Rohani, 2017; Lizawati, 2015; Wuryandani et al., 2014). Pada tradisi pamali di Leuweung Kramat Kampung Adat Kuta terdapat dua aturan yang dapat membentuk sikap disiplin, yaitu dilarang memasuki Leuweung Kramat selain Senin dan Jumat, serta harus membersihkan muka/tubuh di Ciasihan yang ada di Leuweung Kramat.

\section{Dilarang memasuki Leuweung Kramat selain Senin dan Jumat}

Dilarangnya memasuki Leuweung Kramat selain Senin dan Jumat merupakan sebuah aturan untuk menciptakan kedisiplinan. Tidak ada orang yang boleh memasuki Leuweung Kramat dengan sesuka hati. Semua orang harus mengikuti aturan (waktu) yang telah ditentukan, walaupun dalam kondisi darurat. 
Semua orang harus menahan diri, termasuk juga masyarakat setempat. Hal tersebut berkaitan dengan asal mula Leuweung Kramat. Dari tuturan juru kunci/kuncen, Senin dan Jumat merupakan hari bersejarah karena dahulu kala diadakan sayembara, siapa yang lebih dulu mencapai Leuweung Kramat, maka akan dijadikan penguasa daerah tersebut yang merupakan kawasan kekuasaan Kerajaan Cirebon. Sayembara tersebut diikuti oleh dua orang yang sakti, Ki Bumi dan Ki Batasela. Orang yang lebih dulu sampai Leuweung Kramat adalah Ki Bumi bertepatan pada Senin, selanjutnya disusul Ki Batasela yang sampai pada Jumat. Dengan demikian, Ki Bumi yang memenangkan sayembara tersebut. Ki Bumi menawarkan kepada Ki Batasela untuk menjadi abdi dan bersama-sama mengurus Kampung Kuta, namun tawaran tersebut ditolak dan Ki Batasela memilih tinggal di luar Kampung Kuta.

\section{Membersihkan muka/tubuh di Ciasihan yang ada di Leuweung Kramat}

Nilai kedisiplinan tercermin dari adanya tradisi membersihkan muka/tubuh di Ciasihan. Ciasihan merupakan tempat mata air yang ada di Kampung Adat Kuta yang tidak pernah kering bahkan ketika musim kemarau. Masyarakat Kampung Adat Kuta beranggapan bahwa air tersebut dapat menyucikan diri seseorang yang akan meminta restu kepada leluhur. Hal tersebut menjadi salah satu syarat untuk melakukan ritual permohonan. Ketika seseorang akan meminta restu kepada leluhur harus (wajib) dalam keadaan suci. Masyarakat Kampung Adat Kuta menganggap hutan keramat merupakan tempat yang suci, sehingga masyarakat memberlakukan aturan-aturan untuk menjaga kelestarian hutan (Masduki, 2015).

Kedua aturan dalam disiplin tersebut mengandung nilai yang patut diwariskan kepada generasi muda. Nilai disiplin dapat dilihat dari sikap masyarakat Kampung Adat Kuta sehari-hari yang masih kental menjunjung sebuah tradisi, sehingga terbentuk sebuah sistem peraturan lokal yang berkembang. Dengan adanya aturan-aturan yang berlaku, membuat siapa saja yang akan memasuki Leuweung Kramat tidak dapat berlaku semaunya. 
Edukasi: Jurnal Pendidikan, Volume 19 Nomor 1 Tahun 2021

Nilai Moral dan Sosial Tradisi Pamali.......

Hendry Sugara, Teguh Iman Perdana

Halaman 1-15

\section{Peduli lingkungan}

Sikap peduli lingkungan dapat dilihat dari perilaku yang mengindahkan atau memperhatikan alam sekitar. Sikap peduli lingkungan tergambar dari tidak mengganggu atau merusak alam sekitar. Menjaga lingkungan dengan cara mengelolanya dengan baik, tidak merusak ekosistemnya, dan melakukan upaya perbaikan sehingga akan memberikan manfaat yang dapat dirasakan secara terusmenerus merupakan sikap peduli lingkungan (Purwanti, 2017; Rianto, 2015). Terdapat empat larangan di Leuweung Kramat Kampung Adat Kuta yang mencerminkan sikap peduli lingkungan, yaitu: dilarang memakai alas kaki saat memasuki Leuweung Kramat; dilarang membuang kotoran; dilarang membawa senjata tajam; dan dilarang mengganggu kehidupan binatang di Leuweung Kramat.

\section{Dilarang memakai alas kaki saat memasuki Leuweung Kramat}

Larangan bermula saat Dewi Naganingrum bersembunyi di Leuweung Kramat dari kejaran pengawal Kerajaan Galuh. Dahulu kala, alas kaki menandakan status sosial, hanya keluarga raja saja yang memakainya. Oleh karenanya, Dewi Naganingrum tidak menggunakan alas kaki agar jejak kakinya tidak ditemukan dengan mudah oleh para pengawal. Masyarakat Kampung Adat Kuta memiliki sikap yang sederhana serta patuh terhadap norma-norma. Masyarakat sangat menghormati tempat keramat peninggalan leluhur. Tempat keramat yang dimaksud adalah hutan keramat yang dihuni oleh makhluk-makhluk gaib, sehingga siapa saja yang masuk ke hutan tersebut tidak boleh menggunakan alas kaki (Fajarini \& Dhanurseto, 2019). Menggunakan alas kaki ketika masuk ke Leuweung Kramat sangat dilarang. Hal tersebut karena jika seseorang menggunakan alas kaki saat masuk ke Leuweung Kramat, maka akan melangkah dengan sembarangan. Akan banyak tumbuhan atau hewan terinjak dengan langkah yang bebas tersebut. Berjalan tanpa menggunakan alas kaki, seseorang lebih hati-hati dalam melangkah.

\section{Dilarang membuang kotoran}

Leuweung Kramat dianggap tempat suci oleh masyarakat sekitar, sehingga untuk menjaga kesuciannya masyarakat dilarang membuang kotoran di dalamnya. 
Hal tersebut berkenaan dengan Leuweung Kramat yang dijadikan tempat untuk memohon restu pada para leluhur agar apa yang diinginkan dapat berjalan dengan baik. Masyarakat Kampung Adat Kuta sangat menjaga kebersihan. Hubungan antara manusia dan alam juga sangat dijaga. Jadi, jika ada orang yang membuang kotoran sembarangan, maka akan berdampak terhadap lingkungan (Fajarini \& Dhanurseto, 2019).

\section{Dilarang membawa senjata tajam}

Larangan membawa senjata tajam ketika memasuki Leweung Kramat bertujuan agar tanaman atau pohon yang telah lama ditanam oleh para leluhur tidak rusak dan dijaga hingga kini. Seseorang yang membawa senjata tajam (seperti golok, kapak, arit) memungkinkan untuk melakukan pomotongan dahan/pohon yang menghalangi perjalanannya di Leuweung Kramat. Banyak juga pohon yang berukuran besar tumbuh di Leuweung Kramat. Dikhawatirkan dengan membawa senjata tajam ke Leuweung Kramat, ada orang-orang yang tidak bertanggung jawab melakukan penebangan pohon untuk keperluan pribadi. Hal tersebut sesuai dengan Undang-Undang Republik Indonesia Nomor 18 Tahun 2013 tentang Pencegahan dan Pemberantasan Perusakan Hutan yang tertera dalam Pasal 12 (poin f) yang isinya adalah setiap orang dilarang membawa alat-alat yang lazim digunakan untuk menebang, memotong, atau membelah pohon di kawasan hutan tanpa izin pejabat yang berwenang.

\section{Dilarang mengganggu kehidupan binatang di Leuweung Kramat}

Banyak binatang yang hidup bebas di Leuweung Kramat. Masyarakat dilarang mengganggu kehidupan binatang dengan menangkap atau membunuhnya. Hal tersebut berhubungan dengan kepercayaan masyarakat Kampung Adat Kuta yang menganggap bahwa binatang-binatang yang berada di Leuweung Kramat tidak semuanya binatang asli, melainkan para leluhur yang berubah bentuk menjadi binatang. Hal tersebut juga sesuai dengan Undang-Undang Nomor 5 Tahun 1967 tentang Ketentuan-Ketentuan Pokok Kehutanan Pasal 16 yang berbunyi pemburuan swasta liar diatur dengan peraturan perundangan dengan 
Edukasi: Jurnal Pendidikan, Volume 19 Nomor 1 Tahun 2021

Nilai Moral dan Sosial Tradisi Pamali.......

Hendry Sugara, Teguh Iman Perdana

Halaman 1-15

mengindahkan tujuan-tujuan yang telah ditetapkan. Larangan/aturan tersebut mengandung nilai peduli lingkungan yang dimaksudkan untuk menjaga kelestarian Leuweung Kramat. Nilai peduli lingkungan dapat diturunkan kepada generasi muda guna menjaga alam tetap lestari. Mengingat seiring perkembangan zaman, banyak yang merusak alam demi kepentingan/keuntungan kelompok atau pribadi.

\section{Nilai Sosial dalam Tradisi Pamali di Kampung Adat Kuta}

Nilai sosial berhubungan dengan cara hidup bermasyarakat. Nilai sosial merupakan hal yang dijadikan ukuran atau penilaian untuk menyatakan pantas atau tidak suatu sikap di masyarakat (Aisah, 2015). Manusia adalah makhluk sosial yang hidup berkelompok dan saling membutuhkan satu sama lain. Hal tersebut diwujudkan dalam bentuk sikap tolong-menolong dan berinteraksi dengan sesama maupun dengan alam guna menjalani hidup dengan baik. Nilai sosial meliputi rendah hati dan kesopanan. Nilai rendah hati terdiri dari terdiri dari dilarang memakai perhiasan saat memasuki Leweung Kramat dan dilarang memakai seragam/dinas. Nilai kesopanan terdiri dari dilarang berbicara kasar dan dilarang memasuki Leuweung Kramat tanpa didampingi juru kunci/kuncen.

\section{Rendah hati}

Nilai rendah hati tergambar dari perilaku yang tidak menunjukkan sikap sombong atau merasa diri lebih tinggi daripada orang lain. Rendah hati dapat mencerminkan kecerdasan interpersonal dan intrapersonal seseorang (Ningrum et al., 2015). Terdapat dua larangan dalam tradisi pamali di Leuweung Kramat Kampung Adat Kuta yang menunjukkan nilai rendah hati, yaitu dilarang memakai perhiasan saat memasuki Leweung Kramat dan dilarang memakai seragam/dinas.

\section{Dilarang memakai perhiasan saat memasuki Leweung Kramat}

Larangan memakai perhiasan berkaitan dengan keduniawian dan kemewahan. Masyarakat Kampung Adat Kuta memercayai bahwa para leluhurnya dulu hidup dengan penuh kesederhanaan. Hidup berpasrah kepada Yang Mahakuasa dan menerima apapun dengan rasa syukur. Para leluhur meninggalkan 
semua hal-hal yang berkaitan dengan keduniawian, karena dunia bukanlah tujuan hidup. Kehidupan abadi yang diinginkan bukanlah dunia, sehingga bukan hal yang sulit meninggalkan perkara dunia. Untuk menghormati kepercayaan tersebut, maka seseorang yang memasuki Leuweung Kramat harus menanggalkan perhiasan yang dikenakan. Hal tersebut juga menunjukkan bahwa orang yang ingin masuk ke Leuweung Kramat memiliki niatan baik dengan mengenyampingkan hal duniawi. Hal duniawi diidentikkan dengan keserakahan.

\section{Dilarang memakai seragam/dinas}

Larangan memakai seragam/dinas berkaitan dengan larangan memakai alas kaki ketika memasuki Leuweung Kramat yaitu ketika Dewi Naganingrum bersembunyi dan melepaskan baju kebesarannya sebagai seorang putri dan memakai pakaian sederhana. Hal tersebut menunjukkan bahwa pakaian dapat menjadi ciri status sosial/jabatan seseorang. Akan timbul kesombongan atas diri sendiri kepada orang lain dengan status sosial/jabatannya. Setiap orang yang masuk ke Leuweung Kramat dianggap memiliki kedudukan yang sama, walaupun memiliki maksud dan tujuan yang berbeda-beda. Masyarakat Kampung Adat Kuta merupakan masyarakat yang sederhana dan tidak mengagungkan sebuah kemewahan atau hal yang bersifat keduniawian. Nilai tersebut harus diwarisakan pada generasi muda yang cenderung mengutamakan hal yang bersifat duniawi.

\section{Kesopanan}

Kesopanan secara bahasa dapat diartikan sebagai salah satu kemampuan sosial yang memungkinkan orang bisa berinteraksi dengan orang lain dan diterima dalam suatu budaya tertentu (Sudartini, 2010). Kesopanan berhubungan dengan adat sopan santun, tingkah laku yang baik, dan tata krama. Dari tradisi pamali di Kampung Adat Kuta, nilai kosopanan terdiri dari dilarang berbicara kasar dan dilarang memasuki Leuweung Kramat tanpa didampingi juru kunci/kuncen. 
Edukasi: Jurnal Pendidikan, Volume 19 Nomor 1 Tahun 2021

Nilai Moral dan Sosial Tradisi Pamali.......

Hendry Sugara, Teguh Iman Perdana

Halaman 1-15

\section{Dilarang berbicara kasar}

Leweung Kramat dipercaya sebagai tempat suci, sehingga saat memasukinya seseorang dilarang untuk berbicara yang tidak pantas atau tidak baik, apalagi sampai menentang penjaga Leuweung Kramat. Kepercayaan tentang Leuweung Kramat diwariskan secara turun-temurun oleh masyarakat Kampung Adat Kuta. Leuweung Kramat dianggap tempat sakral dan suci sehingga perlu diberlakukan aturan agar dapat menjaga kesakralan dan kesucian Leuweung Kramat tersebut, salah satunya dengan dilarang untuk berkata tidak sopan di Leuweung Kramat (Firmansyah \& Putrisari, 2017; Yuniarti, 2013).

\section{Dilarang memasuki Leuweung Kramat tanpa didampingi juru kunci/kuncen}

Sudah menjadi suatu keharusan apabila memasuki Leuweung Kramat didampingi oleh juru kunci/kuncen. Hal tersebut karena juru kunci merupakan keturunan langsung dari para leluhur, sehingga akan lebih paham seluk-beluk Leuweung Kramat. Juru kunci juga berperan sebagai perantara antara dunia nyata dan dunia gaib. Juru kunci memiliki kemampuan tersebut karena diwariskan oleh orang tuanya secara turun-temurun tiap generasi.

Kedua larangan tersebut mencerminkan sikap kesopanan. Seseorang dalam berperilaku harus sopan dan santun serta menghargai adat/peraturan masyarakat setempat. Kampung Adat Kuta memiliki tradisi pamali yang harus ditaati oleh siapa saja yang berada di lingkungannya. Jika ada yang melanggar aturan tersebut, tidak hanya yang bersangkutan yang menerima akibatnya, namun seluruh masyarakat juga akan terkena dampaknya. Jika ada yang melanggar aturan di Kampung Adat Kuta, maka akan terkena penyakit, hama tanaman akan datang, akan terjadi gempa bumi dan tanah longsor, bahkan sampai dengan kematian (Aulia \& Dharmawan, 2010).

Semua masyarakat Kampung Adat Kuta ataupun orang luar yang dating, sampai sekarang selalu mengikuti aturan-aturan yang berlaku. Semua yang dilakukan oleh masyarakat Kampung Adat Kuta merupakan praktik pelestarian lingkungan. Semua aturan yang berlaku tidak hanya untuk komunitas masyarakatnya saja, melainkan seluruh orang yang berada di lingkungan Kampung 
Adat Kuta (Suwarlan et al., 2020). Kampung Adat Kuta memiliki hutan keramat yang sering didatangi orang yang bermaksud untuk meminta kebahagiaan dan keselamatan, namun tidak boleh bagi siapapun yang masuk Leuweung Kramat untuk meminta sesuatu yang berhubungan dengan ketamakan (Firmansyah \& Putrisari, 2017).

\section{SIMPULAN}

Berdasarkan hasil penelitian, dapat disimpulkan bahwa tradisi pamali yang ada di Leuweung Kramat Kampung Adat Kuta memiliki berbagai nilai-nilai pendidikan karakter. Nilai-nilai tersebut terdiri atas nilai moral dan sosial. Nilai moral meliputi sikap disiplin yang menunjukkan perilaku taat terhadap tata tertib atau peraturan yang berlaku dan sikap peduli lingkungan yang tergambar dari tidak mengganggu atau merusak alam sekitar. Nilai sosial meliputi sikap rendah diri yang tergambar dari perilaku yang tidak menunjukkan sikap sombong atau merasa diri lebih tinggi daripada orang lain dan kesopanan terlihat dari perilaku yang sopan santun atau menunjukkan tingkah laku yang baik. Kearifan budaya lokal merupakan inti dari nilai-nilai pendidikan karakter. Masyarakat Kampung Adat Kuta menjadikan Leuweung Kramat sebagai simbol keberlangsungan kebudayaan. Masih terjaganya Leuweung Kramat merupakan tanda bahwa budaya di Kampung Adat Kuta tidak berubah seiring berkembangnya zaman.

\section{DAFTAR PUSTAKA}

Adri, J., Ambiyar, Refdinal, R., Giatman, M., \& Azman, A. (2020). Perspektif pendidikan karakter akhlak mulia pada perubahan tingkah laku siswa. Edukasi: Jurnal Pendidikan, 18(2), 170-181. http://dx.doi.org/10.31571/ edukasi.v18i2.1845.

Aisah, S. (2015). Nilai-nilai sosial yang terkandung dalam cerita rakyat "Ence Sulaiman" pada masyarakat Tomia. Jurnal Humanika, 3(15), 1-19.

Alma, B. (2010). Pembelajaran Studi Sosial. Bandung: Alfabeta. 
Edukasi: Jurnal Pendidikan, Volume 19 Nomor 1 Tahun 2021

Nilai Moral dan Sosial Tradisi Pamali.......

Hendry Sugara, Teguh Iman Perdana

Halaman 1-15

Anggraeni, R. (2018). Tradisi babarit sebagai model bahan ajar kearifan lokal di SMA (kajian semiotik dan etnopedagogik). Jurnal Lokabasa, 9(1), 73-86. https://doi.org/10.17509/jlb.v9i1.15674.

Aulia, T. O. S., \& Dharmawan, A. H. (2010). Kearifan lokal dalam pengelolaan sumberdaya air di Kampung Kuta. Sodality: Jurnal Transdisiplin Sosiologi, Komunikasi, dan Ekologi Manusia, 4(3), 345-355. https://doi.org/10.17509/ jlb.v9i1.15674.

Budiarto, G. (2020). Indonesia dalam pusaran globalisasi dan pengaruhnya terhadap krisis moral dan karakter. Pamator Journal, 13(1), 5056. https://doi.org/10.21107/pamator.v13i1.6912.

Chastanti, I., \& Munthe, I. K. (2019). Pendidikan karakter pada aspek moral knowing tentang narkotika pada siswa menengah pertama. Sosial Horizon: Jurnal Pendidikan Sosial, 6(1), 26-37. http://dx.doi.org/10.31571/sosial. v6i1.994.

Fajarini, S. D., \& Dhanurseto. (2019). Penerapan budaya pamali dan adat istiadat dalam kehidupan masyarakat Kampung Adat Kuta Kabupaten Ciamis Jawa Barat. Jurnal Profesional, 6(2), 23-29. https://doi.org/10.37676/ professional.v6i2.942.

Firmansyah, E. K., \& Putrisari, N. D. (2017). Sistem religi dan kepercayaan masyarakat Kampung Adat Kuta Kecamatan Tambaksari Kabupaten Ciamis. Jurnal Pengabdian Kepada Masyarakat, 1(4), 236-243.

Hemafitria. (2019). Nilai karakter berbasis kearifan lokal tradisi tepung tawar pada etnis Melayu Sambas. Jurnal Pendidikan Kewarganegaraan, 3(2), 121-132. http://dx.doi.org/10.31571/pkn.v3i2.1435.

Herlina. (2014). Nilai kearifan lokal dalam novel Negeri Sapati karya Laode. M. Insan sebagai pendukung pelaksanaan pendidikan karakter. Jurnal Pendidikan Bahasa, 3(2), 201-210. http://dx.doi.org/10.31571/bahasa. v3i2.166.

Hikmat, H. (2010). Strategi pemberdayaan masyarakat. Bandung: Humaniora Utama Press. 
Lestari, S., \& Rohani. (2017). Penanaman karakter peduli sosial di Sekolah Menengah Pertama Negeri 1 Tangaran Kabupaten Sambas. Jurnal Pendidikan Kewarganegaraan, 1(2), 172-180. http://dx.doi.org/10.31571/ pkn.v1i2.608.

Lizawati. (2016). Nilai pendidikan karakter dalam novel Surat Kecil untuk Tuhan karya Agnes Davonar (Kajian semiotik). Jurnal Pendidikan Bahasa, 5(2), 227-241. http://dx.doi.org/10.31571/bahasa.v5i2.327.

Masduki, A. (2015). Kearifan lokal orang Sunda dalam ungkapan tradisional di Kampung Kuta Kabupaten Ciamis. Patanjala, 7(2), 295-310. https://doi.org/ 10.30959/patanjala.v7i2.102.

Mauludea, H., Nurhadianto, \& Islamuddin. (2016). Budaya masyarakat Suku Talang Mamak dalam bagian civic culture. Edukasi: Jurnal Pendidikan, 14(1), 53-68. http://dx.doi.org/10.31571/edukasi.v14i1.285.

Ningrum, M. A., Hanim, W., \& Herdi, H. (2015). Pengaruh bimbingan kelompok dengan metode bermain terhadap perilaku rendah hati siswa kelas II. INSIGHT: Jurnal Bimbingan Konseling, 4(2), 64-68. https://doi.org/ 10.21009/INSIGHT.042.11.

Octavia, E., \& Sumanto, I. (2018). Peran guru Pendidikan Kewarganegaraan dalam membentuk karakter disiplin siswa di sekolah. Jurnal Pendidikan Kewarganegaraan, 2(2), 20-30. http://dx.doi.org/10.31571/pkn.v2i2.955.

Purwanti, D. (2017). Pendidikan karakter peduli lingkungan dan implementasinya. DWIJA CENDEKIA: Jurnal Riset Pedagogik, 1(2), 14-20.

Rachmadyanti, P. (2017). Penguatan pendidikan karakter bagi siswa sekolah dasar melalui kearifan lokal. JPsd (Jurnal Pendidikan Sekolah Dasar), 3(2), 201214. http://dx.doi.org/10.30870/jpsd.v3i2.2140.

Rianto, H. (2015). Peran Pendidikan Pancasila dan Kewarganegaraan membangun generasi cerdas dan berkarakter. Sosial Horizon: Jurnal Pendidikan Sosial, 2(1), 14-21. http://dx.doi.org/10.31571/sosial.v2i1.48.

Saini, K. M. (2004). Krisis kebudayaan (pilihan 10 essai). Bandung: Kelir.

Salfia, N. (2015). Nilai moral dalam novel $5 \mathrm{~cm}$ karya Donny Dhirgantoro. Jurnal Humanika, 3(15), 1-18. 
Edukasi: Jurnal Pendidikan, Volume 19 Nomor 1 Tahun 2021

Nilai Moral dan Sosial Tradisi Pamali.......

Hendry Sugara, Teguh Iman Perdana

Halaman 1-15

Sudartini, S. (2010). Konsep kesopanan berbicara oleh wanita dalam budaya Jawa. Widyaparwa, 38(1), 27-34. https://doi.org/10.26499/wdprw.v38i1.6.

Susilo, D., \& Rahmat K. (2009). Sosiologi lingkungan. Jakarta: Rajawali Press.

Suwarlan, E., Endah, K., \& Nurulsyam, A. (2020). Peran lembaga adat Kampung Kuta dalam pelestarian lingkungan hidup berbasis kearifan lokal di Kabupaten Ciamis. Jurnal Agregasi, 8(2), 114-128. https://doi.org/ 10.34010/agregasi.v8i2.3289.

Undang-Undang Nomor 18 Tahun 2013 tentang Pencegahan dan Pemberantasan Perusakan Hutan dalam https://peraturan.bpk.go.id/Home/Details/38884/ uu-no-18-tahun-2013. Diakses 17 Februari 2021.

Undang-Undang Nomor 5 Tahun 1967 tentang Ketentuan-Ketentuan Pokok Kehutanan dalam https://peraturan.bpk.go.id/Home/Details/49554/uu-no-5tahun-1967. Diakses 17 Februari 2021.

Wuryandani, W., Maftuh, B., Sapriya, \& Budimansyah, D. (2014). Pendidikan karakter disiplin di sekolah dasar. Jurnal Cakrawala Pendidikan, 33(2), 286-295. https://doi.org/10.21831/cp.v2i2.2168.

Yuliananingsih. (2015). Pelaksanaan pendidikan karakter di Program Studi Pendidikan Pancasila dan Kewarganegaraan IKIP PGRI Pontianak. Edukasi: Jurnal Pendidikan, 13(2), 239-248. http://dx.doi.org/10.31571/edukasi. v13i2.119.

Yuniarti, N. (2013). Analisis aspek kejiwaan tokoh dan nilai pendidikan karakter novel Surat Dahlan karya Khrtisna Pabichara (Kajian psikologi sastra). Jurnal Pendidikan Bahasa, 2(2), 219-235. http://dx.doi.org/10.31571/ bahasa.v2i2.245. 